\title{
The Use of Frame Story in Kashmira Sheth's Boys without Names
}

\author{
Faisal Laee Etan Alobeytha (Corresponding author) \\ School of Education and Modern Languages, College of Arts and Sciences, Universiti Utara Malaysia, Malaysia \\ E-mail: aserhanfaisal@gmail.com \\ Sharifah Fazliyaton binti Shaik Ismail \\ School of Education and Modern Languages, College of Arts and Sciences, Universiti Utara Malaysia, Malaysia \\ E-mail: sfsi@uum.edu.my \\ Aspalila bt. Shapii \\ School of Education and Modern Languages, College of Arts and Sciences, Universiti Utara Malaysia, Malaysia \\ E-mail: aspalila@uum.edu.my
}

Doi:10.7575/aiac.alls.v.7n.5p.105

URL: http://dx.doi.org/10.7575/aiac.alls.v.7n.5p.105
Received: 17/05/2016

Accepted: 03/08/2016

\begin{abstract}
Authors for young adult literature often present their tales directly through the voice of the story narrators. However, Kashmira Sheth, in her Boys without Names, seeks to present her tale, specifically the issue of child labor, through the use of frame stories which are recounted by two or more narrators. Through frame stories, the authors are able to raise the readers' awareness of child labor. This paper, through narrative theory, sets out to examine the function of frame stories in young adult literature and explores how Kashmira Sheth employs this literature to impart wisdom and the importance of being mindful of other people. The study found that frame stories have a remarkable impact on how the young readers comprehend the themes prevalent in Boys without Names. Frame stories also allow the author to convey moral messages and good virtues to the young adult audience. The use of fables also entertains and amuses the readers. Finally, by incorporating multiple narrators in this novel, the author is able not only to depict the issue of child labor from various perspectives; she also expands insights on child labor and confirms the credibility and reliability of the literary text.
\end{abstract}

Keywords: child labor, fables, frame stories, young adult literature

1. Introduction

Young adult literature (YAL) is an appropriate field for handling the issues of young adults and children as it employs a great number of themes that may have captured the interest of young readers. Some of the themes include sexuality, melancholy, suicide, science fiction, drug and alcohol abuse, identity, familial strife, fear, love, cooperation, friendship, and many others. Louie and Louie (1992) who expound the themes of young adult fiction in their survey observe that some of the themes prevalent in this kind of literature are "suicide or death among family members and friends, the discovery of and interaction with gay males and lesbians, drug and alcohol addiction, incest and child abuse, along with the many thrills associated with puberty" (p.35). The young audience's surrounded environment has a noteworthy impact on their lives (Well, 2000; Gee, Wister \& Mitchell, 2005) and their environment is often portrayed in literature produced specifically for them. The exclusion of their environment in young adult literature will result in writings that are unworkable and marginal since they are not tied to issues that belong to young adults' lives (Blasingame, 2007, p. 12). On the other hand, Bishop (1992) who handles the importance of connecting literature to the culture of the readers argues that "students who do not see their culture reflected in the literature they read may believe that they have no value and little or no importance in society and in school" (p.5).

YAL comprises particular characteristics that are offered through the genre, notably "multi-themed story, tension versus shock effect, memorable characters, accurate facts and details, memorable voice, authentic dialogue, effective/clear writing style, sense of humor, widespread appeal, intriguing openings and memorable closings" (Cole, 2009, p. 61-65). Some of the qualities that are distinctive in YAL include: (1) The characters encountering issues that are familiar to the young readers and the issues usually do not nullify, minimize, or debase them; (2) use of language that is comprehensible to young readers; (3) attractive plots; and (4) the stories are normally written by a group of young readers themselves (Blasingame, 2007, p. 11).

Teachers rarely study the literature of children and young adults and more than often, they do not motivate children to give attention to or criticize this form of literature by taking into account the underlying political context (Harris, 1993). Some teachers do not prefer to use YAL in the schools for the reason that it is very easy to read. But this reason is unreasonable because the aim of teaching is to get the students to learn new vocabulary, literary devices, and 
knowledge. Therefore, novelists have to depict the characters' experiences, their energies to cope, their inspiration to get their aims, and their ecstasy of achievement (Louie and Louie, 1992 p.54). This will help the students and young readers to understand the issue that the text treats it, and to enrich their minds with new knowledge.

This article deals with how the novelist Kashmira Sheth (2010) employs the frame tales in her novel Boys Without Names to bring forth the issue of child labor trafficking from different angles and demonstrates how the Indian child thinks and acts like an adult. The article also aims to highlight the ability of YAL in handling the issue of children and young adults in general and child labors in particular. The effectiveness of the frame story type in attracting the young readers' interest and the ability of this device to teach the young readers the noble virtue of humans are also addressed in this article.

The article is based heavily on narrative research design where different tales from the Boys Without Names novel are singled out and examined in detail. Nine tales which were narrated by Gopal and his mother are analyzed to show how they work together to present a clear picture on child labor in the novel and how they were employed to unify the little victims against the slavery, and by mentioning these tales in addition to the stories of six children, the young readers will definitely raise their awareness against child labor trafficking. Since the six stores of the sweatshop's children demonstrate the conditions that guide the children to be trafficked, and there is a big similarity between them, therefore, this article just handles two of them.

\section{An Overview of the Frame Story as a Narrative Device}

One of the literary techniques that are utilized by novelists is a frame story (frame tale or narrative). This narrative device is in which readers are exposed to the secondary story or several other stories within the main story. It is also called stories within the story, boxing stories, or novellae (Schram,2000). The frame story is introduced as

a narrative whole composed of two distinct but connected parts: a story, or stories, told by a character or several characters in another story of lesser dimensions and subordinate interest, which thus encloses the former as a frame enclosed a picture (Gerhardt,1963, p.395).

There are many forms of story tale. One of which is the teacher - student tale. In the past, teachers often use story tale to convey ethics and impart knowledge to students, notably those from the aristocratic family. When the student poses a question, the teacher responds by illustrating the answer through narrating a story that entertains and teaches the student. One of the artists who used this method is John Gower, Chaucer's close friend. In his Confessio Amantis poem ('the lover's confession'), written in the 1390s, Gower adopted the roles of tutor and narrator in demonstrating many small tales that handle the themes of love, virtue, and moral. In addition to the teacher - student tale, there are also frame tales in the form of entertaining tales that aim to please the audience. A case in point is Scheherazade who was a good storyteller who worked hard to entertain and persuade her husband, the king by telling him different stories night after night. These stories are collected in a book called The Thousand Nights and a Night.

The frame tale was relatively public in Europe in the fourteenth century where audience adaptation was a chief trait of medieval culture (Ong, 1975). This culture focused more on reading and not any other skills. The economy of using words in a novel, therefore, requires a professional narrator who is able to draw the audience's attention to the themes of the novel through the frame story. Otherwise, the reader may not have the stimulus to continue reading the novel (Ong,1975, p.70). The frame story typically occupies a small space in the novel since it is not as significant as the main plot (Davis, 2000, p.70). Indeed, most of the frame stories use "I" in the narration of the story and almost all of them have similar themes that contribute to building the main novel's theme (Davis, 2000, p.70).

The frame story is believed to have its origin from the Indian literature, where its root goes back three millennia (Blackburn, 1986, p. 527), and it appeared early in Europe in the twelfth century when The Seven Sages of Rome or Seven Wise Masters appeared (Campbell, 1899). These stories concern judicious counselors and vicious females where the stories handle the story of a prince who was enticed by his wicked stepmother. The wicked stepmother, who was upset after her love was rejected by the prince, accused the prince of disrespecting her. The prince was sentenced to death. However, he was spared from being killed by seven sages who engrossed the ruler, seven consecutive days, with stories portraying the evil nature of a woman. On the eighth day the young prince, who kept his silence up to that day, decided to defend himself and related what had truly transpired. Upon learning the truth, the ruler ordered that the queen must be executed.

In old Indian literature, the Panchatantra is a collection of stories allocated for a young audience. This collection of stories is big and contains mostly an anthology of animal's tales which concentrate on wisdom (Jafa, 2004, p. 1). In fact, these tales of Panchatantra were translated into many languages, including Arabic in which they are known as 'Kalila wa-Dimna' (the new Persian version is called 'Kalīleh o Demneh) (Wood, 1982). Chaucer (2012) also, in his Canterbury Tales, narrates the pilgrims' stories where the pilgrims play the role of narrator in order to entertain each other during their journey to the Canterbury church. In Emily Brontë's Wuthering Heights, written in 1847, she narrates the story of Heathcliff and Catherine by using the frame tales (2011). In addition to Emily, Anne, her sister, based her novel The Tenant of Wildfell Hall (published in 1884) using this style (Bronte, 2009). Anne Brontë's novel is a collection of a series of letters that were sent by Gilbert Markham to one of his close friends divulging the events that led him to meet his beloved wife. In her Frankenstein novel which was written in 1818, Mary Shelley (2010) also uses this frame where the hero Robert Walton published a letter recounting the story that he heard from Victor Frankenstein. Frankestein deals with the family's story that he lived with. 


\section{The frame tale's characteristics}

Frame tale has many characteristics that distinguish it from other types of tales. These characteristics are: firstly, the frame tale is flexible to some extent. Secondly, it has different themes. Thirdly, it could be a short or a long story, and sport different styles. Fourthly, it may be taken from the tradition of oral and literary as noted by Irwin (1995) who views frame tale as depicting "a series of oral storytelling events in which one or more characters in the frame tale are also narrators of the interpolated tales" (p. 280). Fifthly, the traditional tales could be shifted over time and place through the frame tales. Finally, due its flexibility, frame tale can be adapted to a diversity of linguistic and social environments.

\subsection{Stories within Boys Without Names novel}

As an American author who has an Indian blood in her, Sheth has the desire to reinvigorate the Indian frame story in young adult literature, specifically in American literature. Sheth regrets not writing about her original country India when she articulates "I realize I have not written a single story about my village, friends, and neighbors-about my life" (Sheth, 2010, p.10). The inclusion of several Hindi words in Boys Without Names infuses some elements of realism to the novel and acquaints the readers to some Indian words which can be understood through the story context and the glossary provided in the novel. The insertion of Indian words attests to Sheth's appreciation of her Indian culture.

Sheth employs several points of views through the frame stories that she mentions in the novel. Gopal, the protagonist narrator in the novel, for instance, recounts the story that forms the backbone of the novel, and he also narrates some stories within the main story. In addition to Gopal, Aai 'his mother', and the trafficked children in the sweatshop also contribute to enriching the whole novel through their stories. This framing device allows that readers to access various viewpoints of the tale inside the text, and these viewpoints afford the readers with a great deal of information about the protagonists, specifically the protagonists' inspirations, opinions, and moods.

Sheth also attempts to tie the small tales together in order to provide the audience with one set of related tales. She also aims to provide her readers with multi-different meanings and gives them the opportunity to interpret the text in their own way. Therefore, the reader may alter his or her sense or impression towards the issues prevalent in the novel.

Sheth mobilizes the frame stories by writing about the misery and depression faced by the victims of child labor trafficking in India. She succeeds in her portrayal of child labor in India and is able to send her message across, which is the horror and atrocity of child labor, to the readers in her novel through the use of frame story. The phenomenon of child labor dominates the Indian states. The 2000 estimation (Lieten, 2000) exhibits that there is some 15 million bonded child labor in India, with the majority of them working in farms, sweatshops, brick kilns, pottery, stone quarries, firework and match factories, and many others. Servitude and forced or slave labor are characterized by coercion while bonded labor is a result of a relationship between the creditor and debtor or between the employers and the employees. This relation is supported by coercion and is not necessarily economic even though some of the workers enter the workforce voluntarily due to economic reasons.

The young readers perhaps read the story to amuse themselves but the protagonist Gopal realizes the momentous role of the story in achieving his utmost target which is embedded in liberating the children from the slavery. Through the stories, Sheth tries to drive the attention of the readers to the various circumstances that highlight the causes of child labor trafficking. Therefore, it can be argued that Sheth's selection of the stories is purposeful with different goals. Initially, Gopal utilizes stories to build a strong and unique relation to his peers. His peers were not friendly when he first met them. When he befriends them, he is not sure whom to trust. He is punished by his boss when some of his peers report him to his boss. Gopal realizes that narrating stories help him gain the children's trust and confidence. He is able to create a new, friendly environment and is aware that the children prefer wonderful stories than advice. He knows that stories give him the advantage of being listened to and he becomes close to his peers.

Gopal uses the stories to convey his target and boost the sense of freedom in the mind of the children who do not have any hopes to attain their freedom. The stories conveyed by Gopal encourage and motive the children to pursue better positions in their sweatshop and teach the children to gratify their boss though this action could lead to torments or insults to the others.

Fable is one form of the literature that conveys moral lessons through non-human creatures. Marzolph, Leeuwen, and Wassouf (2004) explain that a fable (Latin fabula which means a telling) "is the fictional story serving as a metaphor for a true event. Its characters are often, but not exclusively, anthropomorphized animals or plants" (p.549). Baldick (1990) defines fable as "a brief tale in verse or prose that conveys a moral lesson, usually by giving a human speech and manners to animals and inanimate things (p.80)". Fables become popular among readers for many reasons. The plots in fables are very simple and their characters, to some extent, are similar to characters in other folktales. In fables, animals, plant and inanimate things have human qualities and these qualities attract both children and young adult readers. The aim of these fable tales is to teach noble virtues and moral values to the readers and inculcate in the minds of the readers about human values through the narration of simple and funny tales. As mentioned earlier, animals in fables behave and communicate like human beings, and fables are old and can be traced to Aesop or before the 6th century B.C. Fables are used to cognize the virtue and moral, to mock human kind, and to convey the political message (Blount, 1975). Blount believes that children do not seek to learn from the fable stories, especially since fables are mainly characterized by animals. However, the adults wish that children would learn from the fables. In contrast, Juel (1988) asserts that children enjoy reading animal stories and prefer to draw pictures of animals. 
It is worthy to mention that some characteristics or attributions of human being are given to animals, and this is called anthropomorphism. For instance, a fox is depicted in several fables where it generally has a negative or sly character, and it has the quality of pretense, ploy, and retaliation. While owl is known for its wisdom and intelligence in Greek mythology, Parrots, on other hand, are the talkative and annoying birds in the fables, and the examples are many.

Bussey (1984) contends that the importance of fables lies in is its ability to affect the mind then the comportment of its audience. Bussey emphasizes that "fables are, in fact, admirably calculated to make lasting impressions on the minds of all persons; but especially those which are unformed and uncultivated ; and to convey to them moral instruction" (p.6). Fable involves usual features that differentiate it from other types like exemplum. Baldick (1990) introduces exemplum as a "short tale used as an example to illustrate a moral point, usually in a sermon or other didactic work" (Baldick, p. 76). In addition to exemplum, there are parable and allegory. Balla (2012) defines parable as:

a parable is a story or short narrative designed to reveal allegorically some religious principle, moral lesson, psychological reality, or general truth (aphoristic aspects. Rather than using abstract discussion, a parable always teaches by comparison with real or literal occurrences -especially "homey" everyday occurrences a wide number of people can relate to (p.31) .

Balla (2012) also introduces allegory as a device that uses "many interconnected symbols or allegorical figures in such as a way that in nearly every element of the narrative has a meaning beyond the literal level" (p. 33). The storyteller of the fable is impersonal, though, on the occasion of modern fables that are written in an entertaining and mocking style, he or she may present arbitrary signs. Fables could be serious and humorous in some cases, and satirical and comical in others. There are numerous types of fable such as a didactic fable that seeks to impart ethical values, a political fable which intends to impact on society by using satiric style, a poetical fable which ambitions to charm audiences, and a pleasurable type. However, in modern education, the fable is used as a tool to give historical experience to students which is in line with Adam's (1980) observation that "the best of these teaching stories are those which teach an important lesson, and which teach it in an interesting way" (Adam, 1980, p.397).

Sheth inserts fables through the narration of stories recounted by both Gopal and his mother. Aai, Gopal's mother attempts to imitate traditional Indian fables in her stories. In the novel, Aai is given the role of a narrator whose function is to calm her children and entertain them. Story telling provides solace to Aai's children and is used as a way to convey social wisdom. Aai narrates the fable of a timid rabbit that stays with its mother although the storm tries to separate them apart. The storm could be metaphorical and symbolizes the moneylenders, Gopal's poverty, injustice society or any reasons that make the family live apart from each other. Gopal views his mother's stories as thought provoking and useful as the stories prepare him and his siblings with similar experiences that they have to face in their lives. The role of storytelling, in the context of the novel, in "passing on wisdom and culture" (Sole \& Wilson, 2002) to other nations and generation is evident in this novel.

Child labors in the sweatshop are no more than slaves in the frame factory which is run by the boss who uses sticks to punish, wear the children off and halt their decision to escape from the drudgery of the factory. The children in Boys without Names consider themselves as inferior to the boss who instills the feeling of depression and makes the children weary and weak, both mental and physical. Sheth continues in using animals in her interpolated stories, and she adds the element of the tree in order to create the image of nature's cooperation against the wicked deeds. This element is one of the literary tropes in myths and writing. In previous epochs, the word 'tree' has special meanings in literature, and it stands for the concept of power, beauty, and mysterious. Gopal narrates the story of Jackal and ants where jackal desires to occupy the house of ants and dismiss them. The latter is terrified of the jackal and agrees to leave their home, except the tree, that has their house under it. The tree motivates them to fight and defeat the jackal because they have the right to stay in their home, and there is no need for them to be afraid of the jackal since they are greater in number whereas there is only one enemy, the jackal. The children in the sweatshop understand the theme of the story and are aware that the jackal is a metaphor that signifies their boss Scar, while the ants refer to them, metaphorically. This story hammers the first nail in the coffin of the boss because the children realize that they are not weak and the time is appropriate to unify them against Scar. It plants a seed of freedom instead of slavery and fear in the minds of the young victims.

The role of the tree is also altered from the role of wisdom and counselor to the role of vicious in one of Aai stories in order to convince their children that not all trees are good; therefore life has bad and good phases. Gopal remembers his mother Aai who used to narrate the story of the big tree and twig where the tree always laughs at the stick because of its weakness. However, a strong wind uproots the tree but the twig only doubles over till the storm stops. Gopal insists on behaving like the stick in order to survive by trying to avoid any confrontation with his boss. He learnt a good lesson from this story that is power and arrogance could not stand in the face of the will of the people, including weak people. He persists in teaching his peers that it is illogical to encounter the power if the person is not in a strong condition therefore, it is better to follow other policies in order to achieve the targets. He invites the child labors to follow these policies in their struggle with their traffickers and slaveholders by avoiding confrontations with their superiors.

Another example of how Gopal incites the children against the boss is his fable about the bull and the calves and how the bull represents the boss and the calves represent the six children. Gopal narrates this story to invite his peers to compare between their condition as slaves and the calves as animals. In spite of their situation, the calves emancipated themselves and the children do not attempt to imitate them. This tale creates what is called the brainstorm when the children realize the facts, and they start inquiring about their future after the emancipation such as Amar who asks "Do the calves go back to their families or stay with each other?"(Sheth, 2010,p. 226). 
Sheth uses the method of comparing the behavior of people to the animals in one of the fables in the novel; Gopal sees how the policeman tries to flatter a very important person (VIP) in a completely opposite way when he insults the poor people. Gopal tries to relate the manners of the jackal (the policeman) towards the lion (VIP) and the behavior of the jackal and the rabbits (the poor people). This picture shows the readers how corrupted the Indian government is in their treatment of those who are rich and those who are poor. This unfair treatment also contributes to the prosper of child labor trafficking.

Gopal uses his talent in narrating the story to obtain the love of his siblings, Naren and Sita. They enjoy listening to his stories and fall to sleep easily as they listen to the stories, particularly during the critical period. Sleep is deemed as necessary to distract them from worrying too much about their deplorable condition. One of those stories that Gopal utilize to narrate to his siblings is the marble story which does not have an ending (Sheth, 2010, p. 284). The reason for this no ending story lies in the explanation given by Gopal's father who remarks "Gopal will finish the story when we get to Jama's house" (Sheth, 2010, p. 17). He assumes that by getting to the city, all his family's difficulties will be resolved. Sheth uses the 'marble'in the novel to represent the great dream. This story teaches the readers virtue and morality, and distracts them from the materialism world; it also aims to confirm that the utmost objective of human beings should not be the wealth but knowledge. Gopal attributes the untold story to his assumption that this story is cursed or one of the evil spirits stole it. He wants the readers to guess the real meaning of the marble when he omits the possibilities that it could be money or jewels. 'Marble' is described as the most beautiful thing. The marble could be a story of the dream for those who believe that there are other things more important than gold.

Sharing expertise by incorporating tales is common in scores of professions. Narrating tales is used as a controlling technique that allows the interchange and consolidation of science, information, and knowledge in the novel. One fictional story that is narrated by Gopal is the Mogul King Akbar story. The Mogul King Akbar story depicts the wit of King Akbar's staff, in particular, nine of his court staff members who compete among each other. Sheth hopes to demonstrate wisdom and intellect confront guile and malevolence. Birbal is King Akbar's smart advisor who uses his mind to clobber other jealous ministers. The story is presented in a humorous way to entertain the young readers. Birbal discloses the trick of the ministers and the barber when they suggest sending Birbal to entertain the dead ancestors of the king. Birbal agrees to go, but after some time, he returns and tells the king that his relatives are very happy and they need the barber to come and cut their hair.

One of Gopal's stories is the story of a bookstore girl who achieved her dream after she found one thousand rupees and returned them to the owner because she is honest, and when he asked her what she wanted in return of her honesty, she asked that he set a small bookshop for her. Her shop became prosperous and she was able to pay all her family's expenditure. Gopal wants to teach his siblings the virtue of being honest and the importance of having dreams. Sheth also singles out the importance of reading and how knowledge improves the life of a nation. This story shows the wisdom of the little girl who selects the bookstore as her reward because she knows that reading is the way to change her current life to the best, so, Sheth chooses a Mumbai story as a name for this story to narrate the story of the progress of Mumbai.

The legends tales about the gods appeared in the old myths, and Sheth hopes to re-introduce the legends of the Gods in her writing. It was Sheth's wish to entertain her readers thorough the legends of Indian gods and how wisdom is connected to the character of Gods. Ganesha (the God of success) and Kartikay (the scientist of God) are the sons of Lord Shiva and Goddess. The two brothers are keen to know who, between the two of them, is wiser. So they consult their parents who ask them to travel around the world, and Ganesha discovers that the world is his parents and he wins. Sheth hopes that this fable can encourage children to think deeply and find the embedded meaning of the novels.

Sheth uses what is called creative nonfiction which needs some sentences. Sheth's styles are echoed by Lee (2007) who views that "ultimately, the key aim of this type of creative nonfiction writer is to communicate information, just like a reporter, but to shape it in a way that reads like fiction" (Lee, 2007, p. xi). The narrator resorts to his memory to narrate his or her story:

A memoir is a tale taken from life - that is, from actual, not imagined occurrences - related by a firstperson narrator who is undeniably the writer. Beyond these bare requirements, it has the same responsibility as the novel or the short story: to shape a piece of experience so that it moves from a tale of private interest to one with meaning for the disinterested reader (Gornick, 2008, p.8).

Sheth also incorporates some of the child labors tales in the sweatshop where they told their stories about the circumstances that lead them to this sweatshop such as the natural disasters - earthquake, drought, and others. In addition to that reason, poverty and the fear of the family's penalty drive those victims to the sweatshop. Sheth summarizes the reasons of the child labors through these tales. The children narrate their stories from their memories after Gopal builds trust between them. Gopal's stories have improved the children's confidence and commitment since these stories motivate them to share their personal stories. Chasin et al (1996) discuss how Boston project, specifically the "public conversation", contributes in building a trust relationship between the individuals or between the groups. At frame factory, personal stories boost reliability and confidence in the minds of the children. These stories give the readers a complete image of the trafficked children' experiences and convey much information about their life. Wilkins (1984) believes that producing commitment is a vital task of organizational tales and mythologies. These stories also play a key role in finding the mutual emotional relation between the narrator and the audiences. Denning (2002) sees that tales have an ingrained ability to engage our sentiments since they handle the irregularities in life, things, people, and circumstances that make people divert from the expected. These unexpected stories induce emotional responses as they warn the readers of being out of control, and at the same time provide a method of understanding the future of the 
people. Szulanski (1996) and Damasio (2000) feel that the emotional echo creates "sticky" knowledge and this means that it is possible to regain one's confidence in the future. For instance, hearing the tale of one of the trafficked children in the selected novel will make the readers think further about their current situation and life in general.

Amar, for example, remembers how his father and stepmother treated him in an inappropriate and degrading manner. This explains why Amar is sent to the frame factory. Roshan also narrates how poverty has hastened his trip to the city and left him laboring in the sweatshop. The traffickers delude the parents by some apocryphal pledges such as a good education, medical care, and respectable accommodation for their children if they travel to the city. Roshan explains how children were traded from the factory to other people like slaves. The process of shifting the children was not covert, and this brings out the corruption of the governments in rural areas and the backwardness of poor people there. The other little victims narrate similar painful stories which lead them to the factory.

\section{Conclusion}

From the above literary analysis, it is clear that Sheth demonstrates her loyalty to her great grandparents' country, India. Using frame stories in her novel for young adult readers assist them in understanding the embedded themes in the novel. Sheth exhibits her proficiency in depicting the portrayal of the child labors in India by mobilizing fables and creative nonfiction inside the frame stories. Her actions and decisions help to revive traditional element of Indian literature through the use of fables. Sheth uses the protagonist Gopal as a wise teacher who optimizes his talents in narrating the stories to build strong relationships with his siblings, parents, and friends in the frame factory. Gopal's talent helps the children to survive and to recover their freedom and identity.

\section{References}

Adams, D. (1980). Teaching Stories for Sociology: The Fables of James Thurber. Teaching Sociology, 7(4), $397-408$. Retrieved from http://www.jstor.org/stable/1316972.

Baldick, C. (1990). The concise Oxford dictionary of literary terms. Oxford, UK: Oxford University.

Balla, b. (2012). Symbolism, synesthesia, and semiotics: multidisciplinary approach. Bloomington, IN: XLIBRIS

Bishop,R,S.(1992) . Children books in multicultural world: A review from the USA. In E.Evans (Ed). Reading Against Racism (p.19-38). Bukkingham: Open University

Blackburn, S. H. (1986). Domesticating the Cosmos: history and structure in a folktale from India. The Journal of Asian Studies, 45(03), 527-543.

Brontë, E. (2011). Wuthering heights. New York,NY: Penguin.

Blasingame, J(2007). Books That Don't Bore 'Em: Young Adult Books That Speak to This Generation. New York, NY: Scholastic.

Blount, M. (1974). Animal land: The creatures of children's fiction. London, UK: Hutchinson.

Brontë, A. (2009). The Tenant of Wildfell Hall. Ontario, Canada: Broadview.

Brontë, E. (2011). Wuthering heights. New York, NY:Penguin.

Bussey, G. (1984). Fables; Original and selected with an introductory dissertation on

the history of fable: Comprising Biographical Notices of Eminent Fabulists. London, UK: Willoughby.

Campbell, K. (1899). A study of the romance of the seven sages with special reference to the middle English versions. PMLA, 14(1), 1-107. doi:1. Retrieved from http://www.jstor.org/stable/456514 doi:1

Chasin, R., Herzig, M., Roth, S., Chasin, L., Becker, C., \& Stains, R. R. (1996). From diatribe to dialogue on divisive public issues: Approaches drawn from family therapy. Mediation Quarterly, 13(4), 323-344.

Chaucer, G .(2012). The Canterbury tales (2nd ed). New York, NY: Broadview

Cole, B.(2009). Young Adult Literature: In the 21st Century. New York, NY: McGraw Hill.

Damascio, A. (2000). The Feeling of What Happens: Body and emotion in the meaning of consciousness. Fort Washington, PA: Harvest Books.

Davis, J (2000). Novelists Essential Guide to Creating Plot . Cincinnati, Ohio: writer's Digest Books.

Denning, S. (2002). "Using Stories to Spark Organizational Change.” Journal of Storytelling and Business Excellence, Retrieved From http://www.storytellingcenter.com/articles.htm.

Gee, E. M. T., Wister, A., \& Mitchell, B. A. (2005). The ethnic and family nexus of homeleaving and returning among Canadian young adults. The Canadian Journal of Sociology, 29(4), 543-575.

Gerhardt ,M.(1963).The Art of Story - Telling: A literary study of the thousand and one night. Leiden, Netherlands: E. J. Brill.

Gornick, V. (2008). Truth in personal narrative. In D, Lazar. Truth in Nonfiction: Essays (pp. 7-10). Iowa city, IA; University of Iowa.

Harris, V. J. (1993). Literature-based approaches to reading instruction. In L. Darling-Hammond (Ed.), Review of Research in Education (pp. 269-297). Washington DC:American Educational Research Association.

Irwin, B. (1995). What's in a frame? The medieval textualization of traditional storytelling. Oral Tradition, 10, $27-53$.

Jafa, M. (2004).Panchatantra world's oldest collection of stories for children. Retrirved From http://dl.ndl.go.jp/view/download/digidepo_998358_po_2004-11-jafa-e.pdf?contentNo=2

Juel, C. (1988). Learning to read and write: A longitudinal study of 54 children from first through fourth grades. Journal of educational Psychology, 80(4), 437.

Lee,G. (2007). The Best Creative Nonfiction. New York, NY: W. W. Norton. pp. xi. 
Lieten, G. (2000). Children, work and education-I: General parameters. Economic and Political Weekly,35(24), 20372043. Retrieved from http://www.jstor.org/stable/4409389

Louie, B., \& Louie, D. (1992). Empowerment through young-adult literature. The English Journal, 81(4), 53-56. doi:1. Retrieved from http://www.jstor.org/stable/819931 doi:1

Marzolph, U., Leeuwen, R., \& Wassouf, W. (2004). The Arabian nights encyclopedia. Santa Barbara, CA: ABC-CLIO. Ong, W. (1975). The writer's audience is always a fiction. PMLA,90(1), 9-21. doi:1. Retrieved from http://www.jstor.org/stable/461344 doi:1

Schram, P. (2000). Stories within stories: From the Jewish oral tradition. Nortbvale,NJ:Jason Aronson.

Shelley, M. W. (2010). Frankenstein: 1818. Intervisual Books: Santa Monica:CA

Sheth, K. (2010). Boys Without Names. New York, NY: Harper Collins.

Sole, D., \& Wilson, D. G. (2002). Storytelling in organizations: The power and traps of using stories to share knowledge in organizations. LILA, Harvard, Graduate School of Education.

Szulanski, G. (1996). Exploring internal stickiness: Impediments to the transfer of best practice within the firm. Strategic management journal,17(S2), 27-43.

Wells, N. M. (2000). At home with nature effects of "greenness" on children's cognitive functioning. Environment and behavior, 32(6), 775-795.

Wilkins, A.L. (1984). The creation of company cultures: The role of stories and human resource systems. Human Resource Management, 23(1), 41-60.

Wood, R. (1982). Kalila and Dimna: Selected fables of Bidpai. London,UK: Granada Paperback. 